\title{
ADSORPTION WAVE OF VANADIUM COMPLEX WITH 2,3-DIHYDROXYBENZALDEHYDE
}

\author{
Ludmila Kiriyak $^{\mathrm{a}}$, Natalia Cecoi ${ }^{\mathrm{a}}$, Tatiana $\mathrm{Cazac}^{\mathrm{a} *}$, Mihail Revenco $^{\mathrm{b} *}$ \\ a Institute of Chemistry, Academy of Sciences of Moldova, MD-2028 Chisinau, \\ 3 Academiei str., Republic of Moldova. \\ ${ }^{\mathrm{b}}$ State University of Moldova, MD-2009 Chisinau, A. Mateevici str., 60, Republic of Moldova. \\ *E-mail: revenco@usm.md; phone 373-22-57-74-04 \\ cazac_t@yahoo.com;phone 373-22-73-97-81
}

\begin{abstract}
The polarographic behavior of the complex formed by $\mathrm{V}(\mathrm{V})$ and 2,3-dihydroxybenzaldehyde $(2,3-$ DHBA $)$ in the solution containing acetate buffer $(\mathrm{pH} 5,2)$ has been investigated. By means of a.c. polarography, chronovoltammetry and other techniques, it has been shown that the electrode process is complicated by the adsorption of 2,3-DHBA and its vanadium complex. The kinetic and adsorption parameters of the electrode process have been determined: adsorption equilibrium constant $\mathrm{B}=1,32 \cdot 10^{5} \mathrm{~mol}^{-1} \cdot \mathrm{dm}^{3}$, the attraction constant $\gamma=1,2$, the maximum surface concentration $\Gamma_{\max }=9,10 \cdot 10^{-11} \mathrm{~mol} \cdot \mathrm{cm}^{-2}$; the share of the electrode surface occupied by one particle of the adsorbed complex $\mathrm{S}=1,81 \mathrm{~nm}^{2}$ and the free adsorption energy $\Delta \mathrm{G}=-39,1 \mathrm{~kJ} \cdot \mathrm{mol}^{-1}$.
\end{abstract}

Keywords: Voltammetry, 2,3-dihydroxybenzaldehyde, vanadium.

\section{Introduction}

Numerous investigations have shown $[1,2]$ that $\mathrm{V}(\mathrm{V})$ interacts easily with substances containing oxygen atoms as donors. The formation of the complexes with hydroxyl-containing ligands is especially characteristic for $\mathrm{V}(\mathrm{V})$. When trihydroxyglutaric acid [3], catechol [4,5], pyragallol [6], catechol violet [7], 2,5-dichloro-3,6-dihydroxy-1,4benzoquinone [8,9], dihydroxynaphthaline [10] and other hydroxyl-containing aromatic compounds [11-14] are added to solution containing $\mathrm{V}(\mathrm{V})$, the formation of the stable complexes has been observed. These species can be adsorbed on the surface of the mercury electrode and reduced considerably easier than $\mathrm{V}(\mathrm{V})$. This behavior made possible to use them in the adsorptive stripping voltammetry with a significant increase of the sensitivity of vanadium determination. The main shortcoming of these methods, as mentioned in [10], is the reagents instability and the overlapping of $\mathrm{V}(\mathrm{V})$ waves as well as the interferences of some metals ions which can be reduced at potentials close to the reduction potential of $\mathrm{V}(\mathrm{V})$. Thus, the solutions of catechol and pyrogallol [4-6] had to be prepared daily due to their quick oxidation by air oxygen. That is why it is often necessary to look for new and more stable ligands able to be used for determination of vanadium.

The purpose of this work is to investigate the electrochemical behavior of $\mathrm{V}(\mathrm{V})$ in the presence of 2,3-dihidroxybenzaldehyde (2,3-DHBA), as well as the peculiarities of the adsorption of the produced complex on the mercury electrode.

\section{Experimental}

Apparatus

Voltammetric measurements were carried out on a PU-1 polarograph (Russia) in a thermostated $(25 \pm 0,1)^{\circ} \mathrm{C}$ three-electrode cell. A three-electrode system consisting of a mercury drop electrode (MDE, 2,45 $\mathrm{mg}^{2 / 3} \mathrm{~s}^{-1 / 2}$ ) as the working electrode, a saturated calomel reference electrode (SCE) and a platinum wire as a auxiliary electrode.

The potential scan rate, $v$, was $2 \mathrm{mV} / \mathrm{s}$, the amplitude of alternating voltage, $\Delta \mathrm{E}$, was $15 \mathrm{mV}$. The drop-time curves were obtained by measuring drop-time in tree-electrode cell with a slowly dropping capillary (12 s).

The voltammetric adsorptive complex waves of $\mathrm{V}(\mathrm{V})$ with 2,3-DHBA were recorded with Model 03 Oscillopolarograph PO-5122 (Russia) with linear-sweep potential: the scan rate - 1,0 V/s; the starting potential - 0,35 V; the delay after the breaking away of the drop - $10 \mathrm{~s}$.

The solution acidity was measured by a universal pH-meter of OP-204/1 type (Hungary). The analyzed solutions were deaerated by electrolytic hydrogen.

\section{Reagents}

Analytical reagent grade chemicals and twice distilled water were used for preparation of the solutions. Stock solution of $\mathrm{V}(\mathrm{V})\left(1 \cdot 10^{-2} \mathrm{~mol} \cdot \mathrm{dm}^{-3}\right)$ was prepared by dissolving the appropriate amount of the sodium metavanadat in a $100 \mathrm{~cm}^{3}$ volumetric flask. The working standard solutions were prepared daily by diluting the stock solution. The $1 \cdot 10^{-3} \mathrm{~mol} \cdot \mathrm{dm}^{-3} 2,3-$ DHBA solution was prepared by dissolving the weighted sample in $1,0-1,5 \mathrm{ml}$ of ethanol in a $100 \mathrm{~cm}^{3}$ volumetric flask followed by addition of the water up to mark. All solutions were prepared in an acetate buffer $\left(0,4 \mathrm{M} \mathrm{CH}_{3} \mathrm{COONa}+0,1 \mathrm{M} \mathrm{CH}_{3} \mathrm{COOH}, \mathrm{pH} 5,2\right)$. 
Procedure

In all cases, the investigated solutions were prepared as follows: an appropriate volume of 2,3-DHBA solution was added to the sodium metavanadat solution in the volumetric flask followed by adding $2.5 \mathrm{~cm}^{3}$ the buffer solution ( $\mathrm{pH}$ 5.2) and diluting with water up to mark.

The solution was transferred into the polarographic cell, deaerated with electrochemically generated hydrogen and an a. c. polarogram was recorded under the following condition: starting potential $\mathrm{E}_{\mathrm{s}}=-0,35 \mathrm{~V}(\mathrm{SCE}), \Delta \mathrm{E}=15 \mathrm{mV}$, $v=2 \mathrm{mV} / \mathrm{s}$.

\section{Results and discussion}

The polarographic behavior of vanadium (V) species is strictly depending on the pH-value of the solutions. In [10] it is shown the presence of diverse vanadium containing forms in solutions with concentrations of $\mathrm{V}(\mathrm{V})<1 \cdot 10^{-5} \mathrm{~mol} \cdot \mathrm{dm}^{-3}$. For the $\mathrm{pH}<3,5$ the dominating particles are $\mathrm{VO}_{2}^{+}$. In the range of $\mathrm{pH} 3,5-7,8$ the formation of the form $\mathrm{VO}_{2}(\mathrm{OH})_{2}^{-}$is favored. For $\mathrm{pH}>8$ the main form present in solution is $\mathrm{HVO}_{4}{ }^{-2}$. The electroreduction of the vanadium containing solutions at $\mathrm{pH} 3,5-7,8$, two waves can be recorded. The first wave characterizes the reduction $\mathrm{VO}_{2}(\mathrm{OH})_{2}{ }^{-}+2 \mathrm{H}^{+}+\mathrm{e} \rightarrow \mathrm{VO}(\mathrm{OH})_{2}+\mathrm{H}_{2} \mathrm{O}$, and the second one - the further reduction of $\mathrm{V}(\mathrm{IV})[1-3]$. The both waves appear at a potential more negative that $-1.0 \mathrm{~V}$ (SCE).

The supporting electrolyte formed by acetate buffer solution, and ensuring the $\mathrm{pH} 5,2$ is inactive up to $\mathrm{E}=-1.0 \mathrm{~V}$. Adding V(V) and 2,3-DHBA, a new well expressed peak can be recorded at the potential -0.590 V. (Fig.1) The height of the peak (Ip) and its potential (E) for a constant concentration of vanadium and 2,3-DHBA are depending on the $\mathrm{pH}$ value of solution.

When $\mathrm{pH}$ is increased, the height of the peak increases and reaches its maximum value in the $\mathrm{pH}$ range of $4,7-5,3$. With the increase of $\mathrm{pH}$, the peak's potential shifts to the more negative values. This is an indicative of hydrogen ions participation in the electrode process.

The increase of the 2,3-DHBA concentration gives rise to the augmentation of the height peak. When the concentration surpasses $1 \cdot 10^{-4} \mathrm{~mol} \cdot \mathrm{dm}^{-3}$ the height remains constant. For a content of vanadium $2 \cdot 10^{-7} \mathrm{~mol} \cdot \mathrm{dm}^{-3}$ the optimal concentration of the organic reagent is $1 \cdot 10^{-4} \mathrm{~mol} \cdot \mathrm{dm}^{-3}$ for a $\mathrm{pH} 5,2$. Under these conditions the signal can be recorded as well expressed peak on the a.c. polarogram.

The height of this peak increases with the increase of $\mathrm{V}(\mathrm{V})$ concentration (Fig. 2, curve 2). The linear dependence of $I_{p}$ with $V(V)$ content was observed in the concentration range $2 \cdot 10^{-7}-5 \cdot 10^{-6} \mathrm{~mol} / \mathrm{dm}^{3}$.

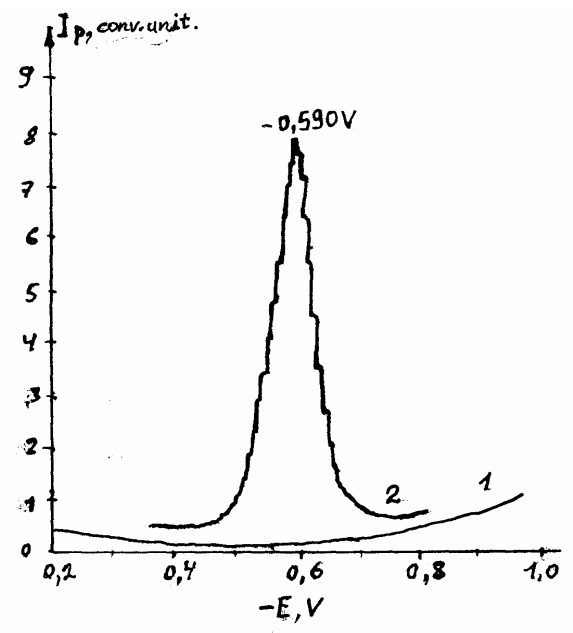

Fig. 1. A. c. Voltammogram of $\mathrm{V}(\mathrm{V})$ :

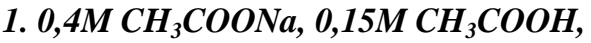
pH 5,$15 ; 2.1+2 \cdot 10^{-6} M V(V)+1 \cdot 10^{-4} M$ 2,3-DHBA $v=2 \mathrm{mV} / \mathrm{s}$, amplitude $15 \mathrm{mV}$, r.c. $0,25 \times 100, \tau=2,1 s, E_{s}=-0,35 V$.

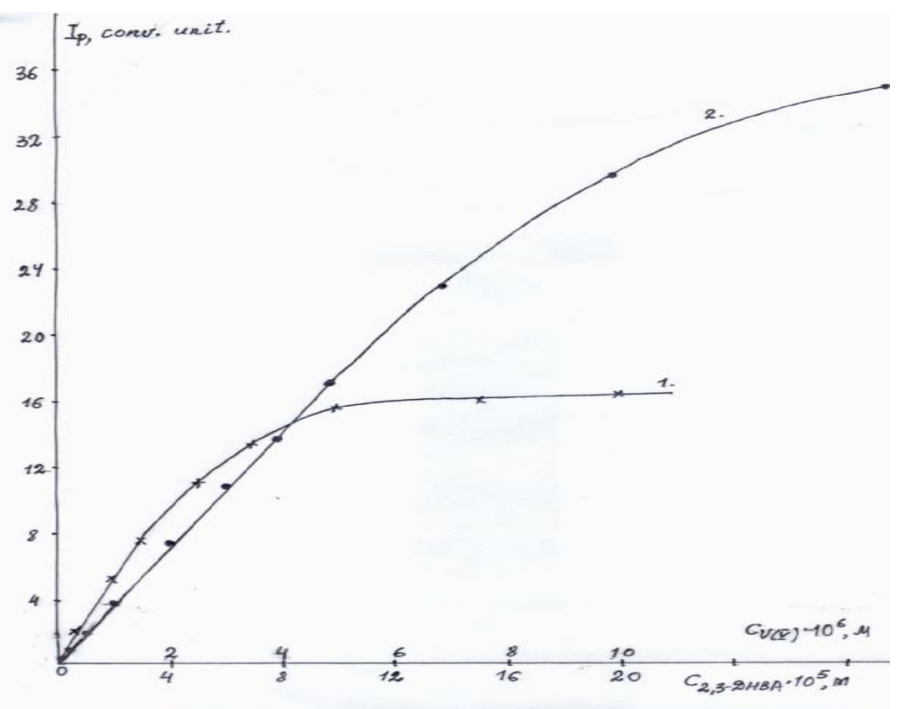

Fig. 2. Dependence of $I_{p}$ on concentration of 2,3-DHBA (curve 1) and $\mathrm{V}(\mathrm{V})$ (curve 2) in solution. Conditions as in Fig. 1.

Using the amperometric titration composition of the formed complexes has been established. As it is seen from Fig. 3, the amperometric curve reflects the following processes occurring in the solution. Up to ratio $\mathrm{V}(\mathrm{V}): 2,3$-DHBA $=1: 1$, vanadium (V) species oxidizes 2,3- DHBA and reaches the oxidation state V(IV). The second section reflects the formation of $\mathrm{V}(\mathrm{IV})$ complex with 2,3-DHBA which finishes at the ratio $\mathrm{V}(\mathrm{IV}): 2,3-\mathrm{DHBA}=1: 3$. In [5] a detailed discussion of the question concerning the formation of the tris-chelate 
complex V(IV) with catechol can be found. Besides that, in the same paper it is emphasized that the tendency of forming tris-chelate complexes is common for ortho-diphenol compounds.

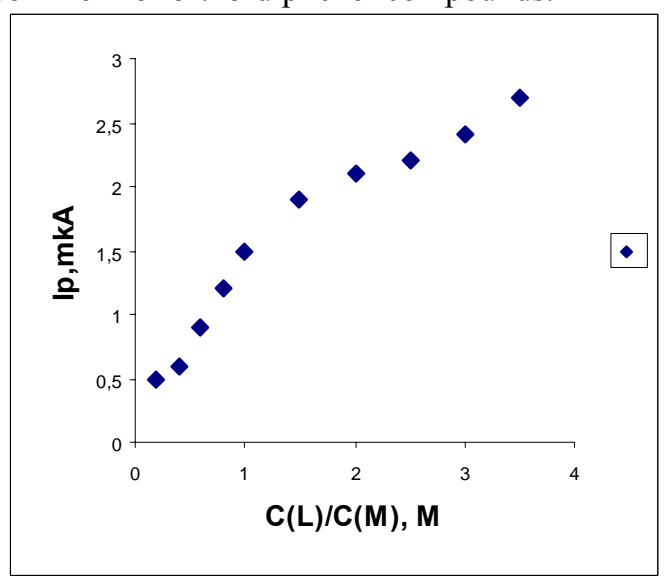

Fig. 3. Amperometric titration curve of vanadium (V) - 2,3-DHBA

In acid aqueous solutions [2], only the following ion pairs : $\mathrm{VO}^{3+}-\mathrm{VO}^{2+} ; \mathrm{VO}^{2+}-\mathrm{V}^{3+} ; \mathrm{V}^{3+}-\mathrm{V}^{2+}$ can exist simultaneously. All other ions combinations of vanadium are impossible due to immediate redox reactions leading to the formation of the above mentioned redox pairs. That is why, in acid solutions it is possible to carry out the process of electrolytic reduction of vanadat- ions according to the scheme:

$$
\mathbf{V}(\mathbf{V}) \stackrel{\mathrm{e}}{\longrightarrow} \mathbf{V}(\mathbf{I V}) \stackrel{\mathrm{e}}{\longrightarrow} \mathrm{V}(\mathrm{III}) \stackrel{\mathrm{e}}{\longrightarrow} \mathrm{V}(\text { II) }
$$

It should be noted that unless all $\mathrm{V}(\mathrm{V})$ is reduced in $\mathrm{V}(\mathrm{IV})$ it is impossible to observe the next step (reduction of $\mathrm{V}(\mathrm{IV})$ ) a. s. o. In our case $\mathrm{V}(\mathrm{V})$ is reduced to $\mathrm{V}(\mathrm{IV})$ by the ligand, while complex V(IV) with 2,3-DHBA is reduced electrochemically on the electrode giving a well expressed peak on the a. c. polarogram in the presence of the acetate buffer ( $\mathrm{pH} 5,2)$ as supporting electrolyte.

For establishing the composition of the complex which is adsorbed on the surface of the mercury electrode, we have used the following equation [11]: $1 / \mathrm{I}_{\mathrm{p}}=1 / \mathrm{I}_{\mathrm{p}, \max }+1 /\left(\beta \mathrm{I}_{\mathrm{p}, \max } \cdot \mathrm{C}_{\mathrm{L}}{ }^{\mathrm{m}}\right)$, where $\mathrm{I}_{\mathrm{p}}$ is the peak's current at a certain concentration of the ligand, $I_{p}$, max is peak's current when all metal ions are bound in a complex, $C_{L}$ is the concentration of the ligand. The dependence $1 / I_{p}$ on $1 / C_{L}{ }^{m}$ is linear only for the case when $m=3$. This result confirms that the electroactive complex on the surface of the electrode is of the same composition as in the solution, i. e. 1:3.

To establish the nature of the current an oscillopolarografic investigation has been undertaken. The height of the peak, recorded in the same condition as was indicated for a.c. polarography, increases simultaneous with the increase of the scan rate. The value of " $X$ " (the slope of dependence $\lg 1_{p}-\lg v$ ) was found to be 0,92 . Such a value of " $\mathrm{X}$ ", as well as the shape of the oscillopolarogram, reminding of an isosceles triangle, is characteristic for electrode processes controlled by adsorption of the complex on the electrode. The value of the current depends on the initial potential and reaches its maximum value at $\mathrm{E}_{\mathrm{s}}=(-0,35-0,45) \mathrm{V}$. The peak's height decreases with the temperature increase. The temperature coefficient is $-2,1 \%$ per degree. All these dependences and the negative value of the temperature coefficient are characteristic for electrode processes complicated by adsorption.

The dependence of drop-time curves on the electrode's potential is shown in Fig. 4.

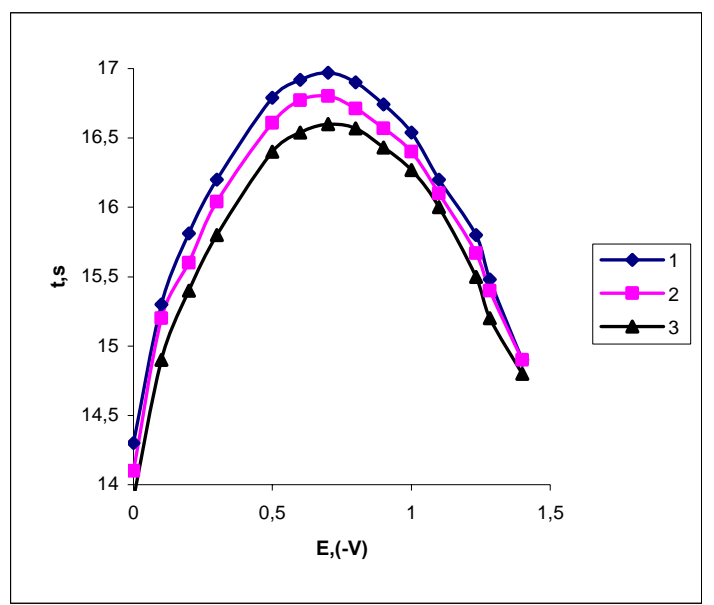

Fig. 4. Drop-time curve: 1. 0,4M $\mathrm{CH}_{3} \mathrm{COONa}-0,15 \mathrm{M} \mathrm{CH} \mathrm{CHOOH}_{3} \mathrm{pH}$ 5.20; $2.1+1 \cdot 10^{-4} M$ 2,3-DHBA; $3.2+2 \cdot 10^{-6} M V(V)$. Conditions as in Fig. 3. 
The introduction of vanadium(V) into the solution containing 2,3-DHBA decreases the drop-time curves (Fig. 5 , curve 3), which is indicative of the fact that adsorption of complexes $V(V)$ with 2,3-DHBA is more significant than the adsorption of the free ligand (Fig. 5, curve 2). The parameters, characterizing the adsorption of $\mathrm{V}(\mathrm{V})$ complexes with 2,3-DHBA on the dropping mercury electrode, has been determined. The maximum surface concentration $\Gamma_{\max }=0,91 \cdot 10^{-6} \mathrm{~mol} \cdot \mathrm{cm}^{2}$ was calculated from the dependence of the discharge current on the complexes concentration. The surface of the electrode per one particle of the adsorbed complex $\mathrm{S}=1,81 \mathrm{~nm}^{2}$ was calculated.

Proceeding from the areas of complexes discharge peaks, the quantity of electricity $(\mathrm{Q})$ was calculated for various concentrations of complexes in the solution [16]. The filling degree $(\theta)$ was determined from relationship $\mathrm{Q} / \mathrm{Q}_{\max }$. The attraction constant $\gamma=1,82$, whose positive value points to the mutual attraction of particles on the electrode's surface, was found from the slope of the straight line in $\lg \theta /(1-\theta) \cdot C-\theta$ coordinates (Fig. 5). The adsorption equilibrium constant $\mathrm{B}=1,32 \cdot 10^{5} \cdot \mathrm{mol}^{-1} \cdot \mathrm{dm}^{3}$ was determined from the same dependence. Using the value of the equilibrium constant, the free adsorption energy $\Delta \mathrm{G}=-39,11 \cdot \mathrm{kJ} \cdot \mathrm{mol}^{-1}$ was calculated.

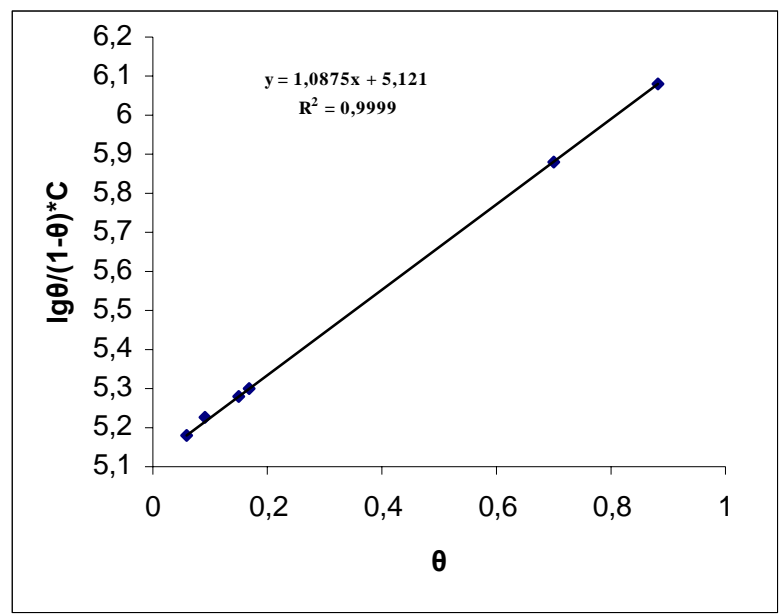

Fig. 5. Isotherm of $V(V)$ - 2,3-DHBA complexes adsorption on the mercury electrode surface. Conditions as in Fig. 3.

\section{Conclusion}

The electrochemical behavior of the vanadium (V) complex of with 2,3-DHBA is controlled by the adsorption of the product on the surface of the mercury electrode. The effect of experimental conditions on the peak of adsorbed species has been studied. The adsorption parameters were determined.

\section{References}

[1]. Музгин, В.Н.; Хамзина, Л.Б.; Золотавин, В.Л.; Безруков, И.Я. Аналитическая химия элементов. Ванадий; М.: Наука, 1981, pp 25-27.

[2]. Гончаренко, А.С. Электрохимия ванадия и его соединений; М.: Металлургия, 1969, pp 49-51.

[3]. Chikryzova, E.G.; Kiriyak, L.G.; Meryan, V.T. Zh. Anal. Khim. 1971, 26, 33-37.

[4]. Van den Berg, C.M.G. ; Huang, Z. A. Anal. Chem.1984, 56, 2383-2386.

[5]. Ivanov, V.D.; Kaplun, M.M. Zh. Anal. Khim. 1997, 52, 362-368.

[6]. Adeloju, S. B. O.; Pablo, F. Anal. Chim. Acta. 1994, 288, 157-222.

[7]. Vucomanovic, D.V.; Van Loon G.W. Talanta, 41, 387-391.

[8]. Sander, S. Anal. Chim. Acta. 1999, 394, 81-89.

[9]. Novotny, L.; Navratil, T.; Sander, S. Electroanalysis 2002, 14, 1105-1109.

[10]. Li, H.; Smart, R.B. Anal. Chim. Acta. 1996, 333, 131-138.

[11]. Lu, J., Jin, W; Wang, S. Anal. Chim. Acta. 1990, 238, 375-381.

[12]. Meryan V. T., Latichewski, I.; Taragan, N.; Zayat, G. Bull. ASM. Ser. Boil. Chem. 1994, N 5, 33-37.

[13]. Pelzer, J.; Scholtz, F., Henrion, G.; Heininger, P. Frezenius Z. Anal. Chem. 1989, 334, 331-336.

[14]. Hsein, A. - K., Ong, T. -H. Mikrochim. Acta. 1991, 3, 117-123.

[15]. Meryan, V. T., Vataman I.I. Zh. Anal. Khim. 1990, 45, 222-232. 